\title{
Macacine Herpesvirus 1 in Long-Tailed Macaques, Malaysia, 2009-2011
}

\author{
Mei-Ho Lee, Melinda K. Rostal, Tom Hughes, Frankie Sitam, Chee-Yen Lee, Jeffrine Japning, \\ Mallory E. Harden, Anthony Griffiths, Misliah Basir, Nathan D. Wolfe, Jonathan H. Epstein, Peter Daszak
}

\begin{abstract}
Macacine herpesvirus 1 (MaHV1; B virus) naturally infects macaques (Macaca spp.) and can cause fatal encephalitis in humans. In Peninsular Malaysia, wild macaques are abundant, and translocation is used to mitigate humanmacaque conflict. Most adult macaques are infected with MaHV1, although the risk for transmission to persons who handle them during capture and translocation is unknown. We investigated MaHV1 shedding among 392 long-tailed macaques ( $M$. fascicularis) after capture and translocation by the Department of Wildlife and National Parks in Peninsular Malaysia, during 2009-2011. For detection of MaHV1 DNA, PCR was performed on urogenital and oropharyngeal swab samples. Overall, $39 \%$ of macaques were shedding MaHV1 DNA; rates of DNA detection did not differ between sample types. This study demonstrates that MaHV1 was shed by a substantial proportion of macaques after capture and transport and suggests that persons handling macaques under these circumstances might be at risk for exposure to MaHV1.
\end{abstract}

$\mathrm{M}$ acacine herpesvirus 1 (MaHV1; also known as B virus) is a zoonotic pathogen that is enzootic among macaque (Macaca spp.) populations throughout Asia $(1,2)$. MaHV1 is an $\alpha$-herpesvirus related to human herpes simplex viruses (HSV) 1 and $2(3,4)$ and to herpesviruses that infect other nonhuman primates such as baboons (5). Like HSV infection in humans, MaHV1 infection in macaques can clinically appear as vesicular lesions on the mucous membranes of the buccal cavity and genital area $(6,7)$. However, macaques without clinically apparent lesions can still shed MaHV1 (6).

Transmission of MaHV1 can occur transcutaneously (via bites) or permucosally (via exposure to macaque body

Author affiliations: EcoHealth Alliance, New York, New York, USA (M-.H. Lee, M.K. Rostal, T. Hughes, C.-Y. Lee, J.H. Epstein, P. Daszak); Department of Wildlife and National Parks Peninsular Malaysia, Kuala Lumpur, Malaysia (F. Sitam, J. Japning, M. Basir); Texas Biomedical Research Institute, San Antonio, Texas, USA (M.E. Harden, A. Griffiths); Metabiota, San Francisco, California, USA (N.D. Wolfe)

DOI: http://dx.doi.org/10.3201/eid2107.140162 fluids) $(8,9)$. Among humans, $\approx 40$ cases of MaHV1 encephalitis have been reported; all patients were laboratory workers who had come in contact with rhesus macaques (M. mulatta) only or with rhesus macaques and long-tailed macaques (M. fascicularis) or their tissues in the research environment $(2,3)$. For these patients, signs and symptoms of MaHV1 infection included skin ulcers and lesions at the site of injury, influenza-like illness, and infection of the peripheral and central nervous systems (which can develop into brainstem encephalomyelitis and death) $(7,9)$. The mortality rate for humans with untreated MaHV1 infection is $>70 \%$ (7). This high case-fatality rate has led to strict regulations for handling macaques and macaque clinical samples in laboratories and resulted in the designation of MaHV1 as a Biosafety Level 4 (BSL-4) pathogen and, until recently, a select agent $(2,7,9)$.

In macaques, MaHV1 frequently remains latent in the trigeminal and lumbosacral ganglia; however, in response to stress, it can be asymptomatically reactivated and shed in saliva and urogenital excretions (10). Macaques typically acquire MaHV1 at sexual maturity (11); previous studies have found IgG against MaHV1 in up to $100 \%$ of sexually mature wild or laboratory long-tailed and rhesus macaques $(11,12)$. As with other viral infections, the presence of $\operatorname{IgG}$ indicates previous exposure or infection but does not indicate active virus shedding. During active infection, MaHV1 DNA can be detected in saliva or urogenital samples by use of PCR. Virus culture is also possible but is not routinely performed because doing so safely requires a BSL-4 laboratory (11). Using PCR as a diagnostic method has advantages over culture in that it can be performed under BSL-2 conditions, it produces results more rapidly, and its sensitivity and specificity are higher $(13,14)$.

Little is known about the shedding rate of MaHV1 in macaques outside the laboratory setting, the frequency of transmission to humans, or the incidence of MaHV1 encephalitis among humans (particularly those with frequent contact with macaques). In Asia, at least $50 \%$ of cases of encephalitis are never diagnosed to the point of causative agent identification (15). Understanding the ecology of MaHV1 among macaques is essential for understanding 
the potential for human infection. Macaques have adapted to urbanized human environments, and contact between humans and macaques can occur in a variety of contexts (e.g., feeding in public recreational areas, capture of wild macaques for the pet trade or biomedical research colonies, consumption, or population management by wildlife authorities). Human-macaque contact can result in bites, scratches, and indirect exposure to macaque body fluids $(16,17)$. Simian foamy virus, a nonpathogenic retrovirus found in nonhuman primates including macaques, has been transmitted during occupational exposure to macaques via bites and scratches in many of the aforementioned contexts and in agricultural, suburban, and urban environments (1820). Zoonotic transmission of simian foamy virus to humans has been demonstrated in Indonesia (18) and Bangladesh (19). Because exposure to MaHV1 can occur through similar routes $(8)$, its transmission under circumstances similar to those of transmission of simian foamy virus in Asia is plausible.

In Peninsular Malaysia, conflict between humans and macaques in residential and public areas results from loss of macaque habitat, successful macaque adaptation to human environments, and subsequent macaque overpopulation. As a result, the Department of Wildlife and National Parks (DWNP) in Peninsular Malaysia implemented a macaque population management program, which includes the removal or translocation of macaques from a conflict area. The possibility of exposure to MaHV1 during macaque capture and transport presents a potential occupational hazard to wildlife personnel.

Our aim with this study was to describe the prevalence of MaHV1 shedding among wild-caught long-tailed macaques after capture and transport in Peninsular Malaysia. This study represents a step toward understanding the potential for zoonotic transmission of MaHV1 outside the laboratory.

\section{Materials and Methods}

\section{Capture and Sample Collection}

Independently of this study, DWNP, as part of their macaque management program throughout Peninsular Malaysia, captured and transported macaques from 6 states (Johor, Perak, Pahang, Pulau Pinang, Selangor, and Negeri Sembilan) to DWNP holding facilities. Capture and opportunistic blood sampling was performed by DWNP and EcoHealth Alliance during September-November 2009, July-October 2010, and July 2011. The macaques captured had been free ranging and lived in the peripheral vegetation of rural, suburban, and urban communities in several states of Peninsular Malaysia. Trapped animals were transferred into transport cages and taken to the nearest local DWNP facility, where they were held up to $72 \mathrm{~h}$ before being transported to the DWNP headquarters in Kuala Lumpur or relocated to a new area. Macaques were kept in groups in cages and provided with food and water throughout the holding period. Animals were captured in accordance with the protocols and guidelines of the Manual for Human-Macaque Conflict Management in Peninsular Malaysia (21). This study was conducted under Institutional Animal Care and Use Committee approval no. 18048 from the University of California (Davis, CA, USA). When handling and sampling macaques, personnel involved with this study wore personal protective equipment (PPE; e.g., eye protection, double-layered nitrile gloves, Tyvek coveralls, and P100 respirators) (22). Blood and swab samples were collected from each animal at its arrival at the headquarters or at the local DWNP facility before relocation. Macaques were immobilized with an intramuscular injection of a combination of $5 \mathrm{mg} / \mathrm{kg}$ ketamine and $5 \mathrm{mg} / \mathrm{kg}$ xylazine (21). After immobilization, oropharyngeal swab and urogenital swab samples were collected (when possible, urine was also collected by cystocentesis). The samples were placed in $2 \mathrm{~mL}$ cryovials (Nalgene Nunc International, Rochester, NY, USA) with $500 \mu \mathrm{L}$ NucliSens lysis buffer (bioMérieux, Marcy l'Étoile, France) and immediately stored at $-80^{\circ} \mathrm{C}$. Macaque weight, body condition, sex, and approximate age were recorded. The age of the animals was determined by assessing their weight, body size, and the development of their incisors and genitals (23). Macaques were categorized as adult ( $\geq 7$ years), subadult (3-6 years), or juvenile (1-3 years). The sex and age of 2 animals and the sex of 1 adult animal were not recorded.

\section{Molecular Testing}

The samples were vigorously mixed; $100 \mu \mathrm{L}$ of the sample was used for mechanical nucleic acid extraction by use of the NucliSENS miniMAG system (bioMérieux). The extracted nucleic acid was eluted with $60 \mu \mathrm{L}$ of buffer. PCR was performed as previously described and validated by Scinicariello et al. (13). Briefly, MaHV1 primers (B virus 1, 5'-ACCTCACGTACGACTCCGACT-3'; and B virus 2, 5'-CTGCAGGACCGAGTAGAGGAT-3'; $2.5 \mu \mathrm{mol} / \mathrm{L}$ ) were each added to the extraction product and HotStarTaq Plus Master Mix (QIAGEN, Hilden, Germany). The product was placed in a thermocyler at $94^{\circ} \mathrm{C}$ for $5 \mathrm{~min}$ and then underwent 30 cycles as follows: $94^{\circ} \mathrm{C}$ for $1 \mathrm{~min}, 56^{\circ} \mathrm{C}$ for $1 \mathrm{~min}$, and $72^{\circ} \mathrm{C}$ for $1 \mathrm{~min}$. The products $(10 \mu \mathrm{L})$ were then analyzed by electrophoresis on $1 \%$ agarose gels. Of the $\approx 10 \%$ of samples that were positive by PCR, 14 PCR products were randomly selected and purified with a PCR purification kit (QIAGEN) and sequenced by using the same primers to confirm identity. Sequences were $128 \mathrm{bp}$ and were analyzed by using a BLAST search of GenBank (24). Because PCR is reported to be highly specific (13) and all 14 PCR products showed $93 \%-100 \%$ nucleotide homology to 
MaHV1, we considered the other PCR products with identical amplicon size to also be positive for MaHV1. PCR is more sensitive than culture for detecting $\operatorname{HSV}(25,26)$, and we considered the detection of MaHV1 DNA in a sample as an indication of virus shedding, although viral load was not obtained through culture or quantitative PCR.

The positive control was produced in a BSL-4 facility and removed from containment by use of inactivation procedures approved by the Texas Biomedical Research Institute Biohazard Committee. Briefly, macacine herpesvirus 1 strain E2490 virion "mini-prep" DNA was generated as previously described (27). With the same B virus 1 and 2 primers, the region between nt 54886 and 54993 was amplified by PCR from the viral genome (13) by using the FailSafe PCR Enzyme Mix (Epicenter, Madison, WI, USA). This region corresponded to a region in the UL28 open reading frame. The resulting 128-nt fragment was cloned into pCR2.1-TOPO by using the TOPO TA kit (Invitrogen, Carlsbad, CA, USA) to generate the pMHUL28 gene. The insert was sequenced and confirmed.

PCR sensitivity (limit of detection) was determined by using DNA from $p M H U L 28$ and 2 confirmed-positive samples by diluting the DNA to copy numbers of $2.71 \times 10^{4}$ for pMHUL2 8 and $1.59 \times 10^{11}$ for the samples. The sensitivity limit for $p M H U L 28$ by PCR was $9.13 \times 10^{2}$ molecules, and for the swab samples it was $\approx 1 \times 10^{4}$ molecules. The PCR sensitivity was previously determined to be $\approx 100$ gene copies by using purified viral DNA, and specificity was determined by SacII restriction enzyme analysis and Southern blot hybridization by using an MaHV1-specific internal probe (5'-GGAGAAGACGTCGCGGTCGTAC-3') that discriminates MaHV1 from HSV (13).

\section{Immunoassay}

A subset of 149 animals, randomly chosen to represent each age group, were tested by the MaHV1 ELISA as described by Ohsawa et al. (28). Although the exact specificity and sensitivity of the original MaHV1 ELISA was not determined, it had been validated by testing of known MaHV1positive $(n=14)$ and negative $(n=6)$ serum, and the assay correctly detected $100 \%$ of the positive samples and provided negative results for $100 \%$ of the negative samples (R. Eberle, pers. comm., 2013). In brief, MaHV1-infected and noninfected cell antigens were added to 96-well roundbottom plates and prepared as previously described (28). Wells were blocked with phosphate-buffered saline containing $5 \%$ bovine serum albumin and $0.05 \%$ Tween 20 (PBS-BSA-Tw) and were incubated at $37^{\circ} \mathrm{C}$ for $1 \mathrm{~h}$, then rinsed with PBS-Tw. Serum samples were diluted to 1:100 with PBS-BSA-Tw, added to the plate $(50 \mu \mathrm{L} /$ well), and incubated at room temperature for $2 \mathrm{~h}$. The wells were washed 5 times with PBS-Tw. Biotinylated anti-human IgG (Vector Laboratories, Burlingame, CA, USA) was diluted 1:5,000 with PBS-BSA-Tw (50 $\mu \mathrm{L} /$ well) and incubated at room temperature for $1 \mathrm{~h}$. The wells were washed 5 times with PBS-Tw. A complex of avidin and biotinylated peroxidase was prepared according to the manufacturer's instructions, diluted to $1: 32$, added to washed wells (50 $\mu \mathrm{L} /$ well), and incubated at room temperature for $1 \mathrm{~h}$. The wells were washed 5 times with PBS-Tw. A 3,3',5,5'-tetramethylbenzidine substrate solution was added $(100 \mu \mathrm{L} /$ well), and the plates were incubated without light for 8-12 $\mathrm{min}$. The reaction was stopped with $2 \mathrm{~mol} / \mathrm{L}$ sulfuric acid $(50 \mu \mathrm{L} /$ well), and the optical density at $450 \mathrm{~nm}$ was measured by using a microplate absorbance reader (Bio-Rad Laboratories, Hercules, CA, USA). An ELISA result was considered positive when the optical density was $>0.1(28)$.

\section{Statistical Analyses}

We calculated standard prevalence rates and 95\% CIs (29) for differences in shedding prevalence based on macaque sample type, sex, and age. For pairwise analysis (2 parameters) of proportions, we conducted a $z$-test. A general linear model was used to investigate the effect of geographic location by state, sex, and age, and the Akaike Information Criterion was used to select the best-fit model (with no significant interactions between the variables). An analysis of variance of the general linear model with a post hoc Tukey HSD (honest significant difference) test was used to assess the significance of each factor. Statistical analyses were conducted by using the R Statistical package (R Core Team, Vienna, Austria). A p value of $\leq 0.05$ was considered statistically significant.

\section{Results}

Samples from 392 long-tailed macaques from 6 states within Peninsular Malaysia (Figure) were screened by PCR; 149 of these were also screened by ELISA (Table 1). The overall detection of MaHV1 DNA in macaques, in urogenital and/or oropharyngeal samples ( $\mathrm{n}=392$ tested), was $39.3 \%(95 \%$ CI $34.5 \%-44.1 \%)$. All 14 sequenced DNA samples displayed 93\%-100\% homology with those of MaHV1. Shedding status did not differ significantly among age groups: $37.6 \%$ (95\% CI $31.2 \%-43.9 \%)$ among 221 adults, $38.8 \%$ (95\% CI 28.1\%-49.4\%) among 80 subadults, and $43.8 \%$ (95\% CI $33.5 \%-54.1 \%$ ) among 89 juveniles (for 2 animals, age was not recorded). Male macaques were more likely than females to be shedding the virus at the time of sampling; prevalence was $44.1 \%$ (95\% CI $37.5 \%-50.7 \%$ ) among 220 males and $33.1 \%$ (95\% CI $26.0 \%-40.2 \%$ ) among 169 females; the sex of 3 animals was not recorded $(z$-statistic $=2.192466$, degrees of freedom $[\mathrm{df}]=1, \mathrm{p}=0.0001)($ Table 1$)$. Males were also significantly more likely than females to shed virus in saliva; prevalence was $26.4 \%$ (95\% CI $20.5 \%-32.2 \%$ ) among 220 males and $16.0 \%$ (95\% CI $10.5 \%-21.5 \%)$ 


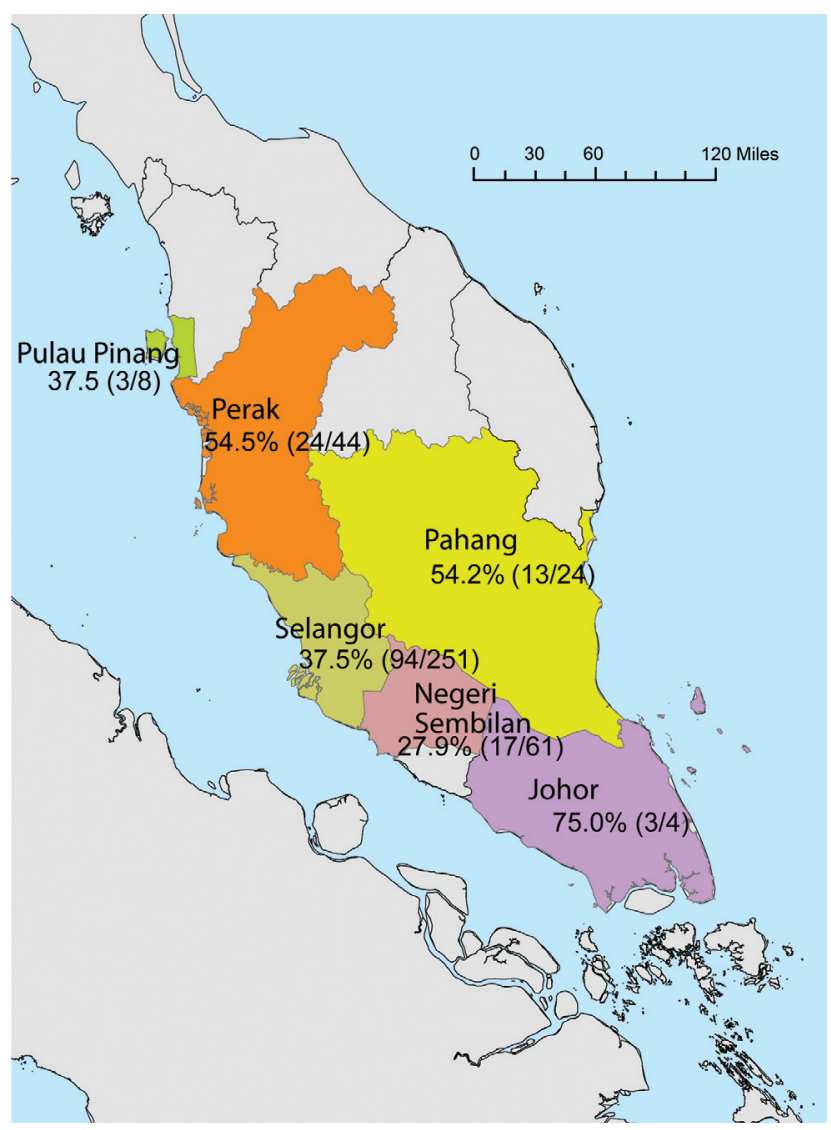

Figure. State of origin and prevalence of macacine herpesvirus 1 shedding within sampled groups of macaques (no. positive/total tested) from Peninsular Malaysia, September 2009-July 2011.

among 169 females $(z$-statistic $=2.457458, \mathrm{df}=1, \mathrm{p}=$ 0.007). Overall, the proportion of urogenital and oropharyngeal samples positive for MaHV1 DNA did not differ significantly: $24.7 \%$ (95\% CI $20.5 \%-29.0 \%)$ of urogenital samples and $21.9 \%(95 \%$ CI $17.8 \%-26.0 \%)$ of oropharyngeal samples were positive. We detected viral DNA in oropharyngeal and in urogenital swabs for $18.8 \%(95 \%$ CI $12.7 \%-25.0 \%$ ) of the 154 macaques with positive results by PCR (Table 2).

Overall, IgG against MaHV1 was found in 73 (49.0\%; $95 \%$ CI $38.5 \%-57.0 \%$ ) of 149 macaques. We found that seroprevalence differed significantly among age groups: IgG was found in $70.0 \%$ of 50 adults, $46.0 \%$ of 50 subadults, and $30.6 \%$ of 49 juveniles $\left(\chi^{2}=15.6333, \mathrm{df}=2, \mathrm{p}\right.$ $=0.0004)$ (Table 3). Among macaques tested by ELISA, $24.2 \%$ (95\% CI $17.3 \%-31.0 \%)$ were positive according to PCR but negative according to ELISA results, although these animals did not differ significantly by age, sex, or shedding site (oropharyngeal vs. urogenital) (Table 4).

The geographic origin of macaques that were MaHV1 positive by PCR was as follows: $4(75.0 \%$; $95 \%$ CI $32.6 \%-$ $100 \%$ ) were from Johor, 44 (54.5\%; 95\% CI 39.8\%-69.3\%) from Perak, 24 (54.2\%; 95\% CI 34.2\%-74.1\%) from Pahang, 8 (37.5\%; 95\% CI 4.0\%-71.0\%) from Pulau Pinang, 251 (37.5\%; 95\% CI 31.5\%-43.4\%) from Selangor, and 61 (27.9\%; 95\% CI 16.6\%-39.1\%) from Negeri Sembilan (Figure). An analysis of variance of the general linear model indicated that both sex and geographic location (state) were significantly associated with detection by PCR, but only the effect of sex (F-statistic $=3.97, \mathrm{df}=1, \mathrm{p}=0.047)$ had enough power to remain significant after a post hoc Tukey HSD (for categorical data) was applied $(\mathrm{p}=0.049)$.

\section{Discussion}

We examined MaHV1 shedding among free-ranging macaques after capture and transport, a scenario under which occupational exposure could occur. In addition to the risk that capture and transport poses for handlers, macaques are probably under increased physiologic stress during capture and transport, which might result in increased virus activation and shedding.

Despite little published data for shedding prevalence in free-ranging or recently captured wild macaques with which to compare our findings, serologic evidence from wild-caught macaques transported from India to the United States in the 1950s for polio vaccine testing indicates that the stress of transport probably led to increased MaHV1 seroprevalence from $10 \%$ before transit to $70 \%$ after transit (30). These animals were young (1.0-1.5 years of age) and were kept in groups of 60 . PCR studies of laboratory macaques (rhesus and long-tail) have reported a shedding prevalence range of $0 \%-71 \%(11,14,31)$. Sample sizes in these studies were generally very small, and most reported

\begin{tabular}{|c|c|c|c|c|c|c|c|c|}
\hline \multirow[b]{3}{*}{ Age group, y } & \multicolumn{2}{|r|}{ Male } & \multicolumn{2}{|r|}{ Female } & \multicolumn{2}{|c|}{ Unspecified $\dagger$} & \multicolumn{2}{|r|}{ Total } \\
\hline & & No. (\%; 95\% Cl) & & No. $(\% ; 95 \%$ Cl) & & No. (\%) & & No. $(\% ; 95 \% \mathrm{Cl})$ \\
\hline & No. & positive & No. & positive & No. & positive & No. & positive \\
\hline Adult, $>6$ & 120 & $55(45.8 ; 36.9-54.7)$ & 100 & $28(28.0 ; 19.2-36.8)$ & 1 & 0 & 221 & $83(37.6 ; 31.2-43.9)$ \\
\hline Subadult, 3-6 & 48 & $19(39.6 ; 25.7-53.4)$ & 32 & $12(37.5 ; 20.7-54.3)$ & 0 & 0 & 80 & $31(38.8 ; 28.1-49.4)$ \\
\hline Juvenile, $<3$ & 52 & $23(44.2 ; 30.7-57.7)$ & 37 & $16(43.2 ; 27.3-59.2)$ & 0 & 0 & 89 & $39(43.8 ; 33.5-54.1)$ \\
\hline Unspecified† & 0 & 0 & 0 & 0 & 2 & $1(50.0)$ & 2 & $1(50.0 ; \mathrm{NA})$ \\
\hline Total & 220 & $97(44.1 ; 37.5-50.7) \ddagger$ & 169 & $56(33.1 ; 26.0-40.2) \ddagger$ & 3 & $1(33.3)$ & 392 & $154(39.3 ; 34.5-44.1)$ \\
\hline
\end{tabular}

${ }^{\star N A}$, not applicable.

$\dagger 2$ macaques of unspecified age and sex and 1 adult macaque of unspecified sex were included in the study.

†Indicates a significant difference $(p<0.05)$ between the 2 groups marked. 
Table 2. PCR results for macacine herpesvirus 1 in macaques, by sample type, Malaysia, 2009-2011*

\begin{tabular}{|c|c|c|c|c|c|c|}
\hline \multirow[b]{2}{*}{ Sex } & \multicolumn{2}{|r|}{ Oropharyngeal } & \multicolumn{2}{|r|}{ Urogenital } & \multicolumn{2}{|c|}{ Oropharyngeal and urogenital } \\
\hline & No. & No. (\%; 95\% Cl) positive & No. & No. (\%; $95 \% \mathrm{Cl})$ positive & No. & No. $(\% ; 95 \% \mathrm{Cl})$ positive \\
\hline $\mathrm{M}$ & 220 & $58(26.4 ; 20.5-32.2) \dagger$ & 220 & $56(25.5 ; 19.7-31.2)$ & 97 & $17(17.5 ; 10.0-25.1)$ \\
\hline $\mathrm{F}$ & 169 & $27(16.0 ; 10.5-21.5) \dagger$ & 169 & $41(24.3 ; 17.8-30.7)$ & 56 & $12(21.4 ; 10.7-32.2)$ \\
\hline Unknown $\ddagger$ & 3 & $1(33.3 ; 0-86.7)$ & 3 & 0 & 0 & 0 \\
\hline Total & 392 & $86(21.9 ; 17.8-26.0)$ & 392 & $97(24.7 ; 20.5-29.0)$ & $29(18.8)$ & $29(18.8 ; 12.7-25.0)$ \\
\hline
\end{tabular}

prevalence rates were $<10 \%$. Shedding prevalence determined in our study certainly falls within these ranges.

We observed that shedding prevalence was significantly higher among male than female macaques, although seroprevalence did not differ. This difference could be related to sociobiological dominance behavior by which females typically remain at the dominance level of their mother, whereas males lose that dominance rank when they leave the group at the time of dispersal. Thus, males continually must earn their ranking as they change groups (32). This behavior might predispose males to greater social stress during capture and transport. Unfortunately, we were unable to separate sexbased differences in physiologic stress from the potential effects of the stress of capture and transport, which might have affected male macaques differently than females.

We observed a significant difference in seroprevalence among macaques in different age groups; seroprevalence was highest among adults. This finding was consistent with findings of previous studies $(11,12)$; however, we did not observe an age-based difference in shedding prevalence. One potential bias in our sampling strategy was that the age groups, which were composed of randomly selected individuals, did not reflect the age ratio of the overall group, which might have contributed to the lack of difference among age groups in shedding prevalence. We had expected to see a lower rate of shedding among juvenile than among adult animals because seroconversion is evident at sexual maturity for most laboratory and free-ranging macaques (33). It could be that younger animals were experiencing primary infection from exposure during capture and transport, which could explain the higher than expected shedding prevalence for this age group and in the overall study.

Our primary aim with this study was detection of MaHV1 DNA in macaques. However, we included serologic test results from a subset of animals to identify antibody seroprevalence among macaques in different age groups and to determine whether shedding occurs in the absence of detectable antibodies. We detected viral DNA in 36 seronegative macaques. This finding may have been the result of a recent primary infection before detectable IgG response. Some animals could have been infected by conspecifics during transport or just before capture. It is also possible that these animals were experiencing acute virus reactivation resulting from the stress of capture and transportation during the $6-72 \mathrm{~h}$ before sampling because previously infected animals would probably be seropositive. Unfortunately, data for the duration of time between capture and sampling were not available. The incubation period for HSV-1 or HSV-2 in humans is 2-12 days (34). Although the time between onset of stress and MaHV1 reactivation has not been determined for macaques, in mice, HSV can reactivate in as little as $14 \mathrm{~h}$ after exposure to a stressor (35). Approximately $80 \%$ of the animals shedding MaHV1 in the absence of detectable IgG were subadults or juveniles, suggesting that this infection was their first.

The low frequency of simultaneous MaHV1 detection in oropharyngeal and urogenital swab samples suggests a variable shedding pattern among individuals, which was not unexpected given the fact that the virus can sequester itself in the ganglia of the trigeminal nerve, sacral nerve $(36,37)$, or both, which would probably affect the route of virus excretion. Other MaHV1 studies have also reported inconsistent detection of virus in oral and genital secretions from infected laboratory macaques sampled repeatedly over time $(11,31)$. Sensitivity of the PCR assay we used was lower than that of the one used by Scinicariello et al. (13), which might have resulted in underdetection of viral DNA in macaque clinical samples. Use of real-time PCR (not available for this study), such as that developed by Huff et al. (38), which has a sensitivity of 10 viral particles,

\begin{tabular}{|c|c|c|c|c|c|c|c|c|}
\hline \multirow[b]{3}{*}{ Age group, y } & \multicolumn{2}{|r|}{ Male } & \multicolumn{2}{|r|}{ Female } & \multicolumn{2}{|c|}{ Unspecified } & \multicolumn{2}{|r|}{ Total } \\
\hline & & No. (\%; 95\% Cl) & & No. (\%; 95\% Cl) & & No. (\%; 95\% & & No. (\%; 95\% Cl) \\
\hline & No. & positive & No. & positive & No. & $\mathrm{Cl}$ ) positive & No. & positive \\
\hline Adult, $>6^{*}$ & 32 & 21(65.6; 49.2-82.1) & 17 & $13(76.5 ; 60.0-96.6)$ & 1 & 1 (100.0; NA) & 50 & 35 (70.0; 53.5-82.7) \\
\hline Subadult, 3-6* & 29 & $12(41.4 ; 23.5-59.3)$ & 21 & $11(52.4 ; 34.5-73.7)$ & 0 & 0 (NA) & 50 & $23(46.0 ; 28.1-59.8)$ \\
\hline Juvenile, $<3^{*}$ & 26 & $8(30.8 ; 13.0-48.5)$ & 23 & $7(30.4 ; 12.7-49.2)$ & 0 & 0 (NA) & 49 & $15(30.6 ; 12.9-43.5)$ \\
\hline Total & 87 & $41(47.1 ; 36.6-57.6)$ & 61 & $31(50.8 ; 40.3-63.4)$ & 1 & $1(100.0 ; \mathrm{NA})$ & 149 & 73 (49.0; 38.5-57.0) \\
\hline
\end{tabular}

${ }^{*}$ Indicates a significant difference $(p<0.05)$ between the age groups marked. 
Table 4. ELISA and PCR results for macacine herpesvirus 1 in macaques, by age, Malaysia, 2009-2011

\begin{tabular}{|c|c|c|c|c|c|}
\hline \multirow[b]{2}{*}{ Age group, y } & \multirow[b]{2}{*}{ No. animals } & \multicolumn{4}{|c|}{ No. $(\%)$ animals } \\
\hline & & $\begin{array}{l}\text { PCR positive, } \\
\text { ELISA positive }\end{array}$ & $\begin{array}{l}\text { PCR positive, } \\
\text { ELISA negative }\end{array}$ & $\begin{array}{l}\text { PCR negative, } \\
\text { ELISA positive }\end{array}$ & $\begin{array}{l}\text { PCR negative, } \\
\text { ELISA negative }\end{array}$ \\
\hline Adult, $>6$ & 50 & $10(20.0)$ & $8(16.0)$ & $25(50.0)$ & $7(14.0)$ \\
\hline Subadult, 3-6 & 50 & $9(18.0)$ & $13(26.0)$ & $14(28.0)$ & $14(28.0)$ \\
\hline Juvenile, <3 & 49 & $4(8.2)$ & $15(30.6)$ & $11(22.4)$ & 19 (38.8) \\
\hline Total & 149 & $23(15.4)$ & $36(24.2)$ & 50 (33.6) & $40(26.8)$ \\
\hline
\end{tabular}

would substantially improve sensitivity of future studies that screen macaques for MaHV1.

The observed MaHV1 shedding patterns suggest that a substantial proportion of animals shed virus after, and potentially during, transport and that the risks for exposure to MaHV1 by wildlife personnel or others handling macaques under these circumstances should be seriously considered. Appropriate PPE, including coveralls, gloves, N95 or P100 respirators, and eye protection, are recommended for wildlife personnel when handling macaques (and any other nonhuman primate) under conditions in which stress and prolonged confinement with other macaques may contribute to increased shedding of MaHV1 and potentially other pathogens. Indeed, as a result of this study, DWNP is strengthening its existing policies requiring personnel handling macaques to wear PPE and use proper work area biosafety and disinfection techniques to reduce the risk for transmission of MaHV1 and other zoonotic pathogens, in accordance with established safety protocols (22). Personnel working with macaques have received additional training to increase their awareness of the potential risks for exposure to MaHV1.

Future studies should determine whether zoonotic transmission has occurred among those who have occupational contact with macaques during procedures such as capture, sample collection, treatment, and translocation (e.g., wildlife personnel) and should determine the incidence rate for infection among high-risk populations. Questions remain about the etiology of viral encephalitides throughout Asia and what proportion of these may be caused by MaHV1. Studies that examine the shedding prevalence of MaHV1 in free-ranging macaques will improve our understanding of shedding in the absence of anthropogenic stressors and, coupled with human surveillance, will enable further assessment of the potential risk for zoonotic transmission. These results will be of particular relevance to professionals who are occupationally exposed to macaques.

\section{Acknowledgments}

We express our gratitude to the wildlife officers and veterinarians of the DWNP in Peninsular Malaysia who provided access to macaques for this study. We thank Richard Eberle for generously providing ELISA plates and technical guidance, Nona Yeoh for facilitating the ELISA, and Parviez Hosseini and Andrew Huff for consultation on statistical methods.
This work was supported by funding from the US Agency for International Development's Emerging Pandemic Threats: PREDICT program, the Skoll Foundation, and Google.org.

Ms. Lee is a research scientist at EcoHealth Alliance, currently working in Kuala Lumpur, Malaysia. Her research interest is the application of molecular and microbiology to public health and conservation.

\section{References}

1. Palmer AE. B virus, herpesvirus simiae: historical perspective. J Med Primatol. 1987;16:99-130.

2. Holmes GP, Chapman LE, Stewart JA, Straus SE, Hilliard JK, Davenport DS. Guidelines for the prevention and treatment of B-virus infections in exposed persons. Clin Infect Dis. 1995;20:421-39.

3. Holmes GP, Hilliard J, Klontz K, Rupert A, Schindler CM, Parrish E, et al. B virus (Herpesvirus simiae) infection in humans: epidemiologic investigation of a cluster. Ann Intern Med. 1990;112:833-9. http://dx.doi.org/10.7326/0003-4819-112-11-833

4. Killeen AM, Harrington L, Wall L, Kelly D. Nucleotide sequence analysis of a homolog of herpes simplex virus type 1 gene US9 found in the genome of simian herpes B virus. J Gen Virol. 1992;73:195-9. http://dx.doi.org/10.1099/ 0022-1317-73-1-195

5. Eberle R, Black DH, Lipper S, Hilliard J. Herpesvirus papio 2, an SA8-like alpha-herpesvirus of baboons. Arch Virol; 1995;140:529-45.

6. Weigler BJ. Biology of B virus in macaque and human hosts: a review. Clin Infect Dis. 1992;14:555-67. http://dx.doi.org/10.1093/ clinids/14.2.555

7. Elmore D, Eberle R. Monkey B virus (Cercopithecine herpesvirus 1). Comp Med. 2008;58:11-21.

8. Centers for Disease Control and Prevention. Fatal cercopithecine herpesvirus 1 (B virus) infection following a mucocutaneous exposure and interim recommendations for worker protection. MMWR Morb Mortal Wkly Rep. 1998;47:1073-6.

9. Cohen JI, Davenport D, Stewart J, Deitchman S, Hilliard J, Chapman L, et al. Recommendations for prevention of and therapy for exposure to B virus (Cercopithecine herpesvirus 1). Clin Infect Dis. 2002;35:1191-203. http://dx.doi.org/10.1086/344754

10. Lees DN, Baskerville A, Cropper L, Brown D. Herpesvirus simiae (B virus) antibody response and virus shedding in experimental primary infection of cynomolgous macaques. Lab Anim Sci. 1991;41:360-4.

11. Huff JL, Barry P. B-virus (Cercopithecine herpesvirus 1) infection in humans and macaques: potential for zoonotic disease. Emerg Infect Dis. 2003;9:246-50. http://dx.doi.org/10.3201/eid0902.020272

12. Engel GA, Jones-Engel L, Schillaci MA, Komang GS, Putra A, Fuentes A, et al. Human exposure to herpesvirus B-seropositive macaques, Bali, Indonesia. Emerg Infect Dis. 2002;8:789-95. http://dx.doi.org/10.3201/eid0808.010467

13. Scinicariello F, Eberle R, Hilliard J. Rapid detection of B virus (Herpesvirus simiae) DNA by polymerase chain reaction. J Infect Dis. 1993;168:747-50. http://dx.doi.org/10.1093/infdis/168.3.747 
14. Black DH, Eberle R. Detection and differentiation of primate $\alpha$-herpesviruses by PCR. J Vet Diagn Invest. 1997;9:225-31. http://dx.doi.org/10.1177/104063879700900301

15. Granerod J, Tam CC, Crowcrof NS, Davies NWS, Borchert M, Thomas SL. Challenge of the unknown: a systematic review of acute encephalitis in non-outbreak situations. Neurology. 2010;75:924-32. http://dx.doi.org/10.1212/ WNL.0b013e3181f11d65

16. Eudey A. The crab-eating macaque (Macaca fascicularis) widespread and rapidly declining. Primate Conservation. 2008;23:129-32. http://dx.doi.org/10.1896/052.023.0115

17. Engel G, Hungerford LL, Jones-Engel L, Travis D, Eberle R, Fuentes A, et al. Risk assessment: a model for predicting crossspecies transmission of simian foamy virus from macaques (M. fascicularis) to humans at a monkey temple in Bali, Indonesia. Am J Primatol. 2006;68:934 48. http://dx.doi.org/10.1002/ajp.20299

18. Jones-Engel L, Engel GA, Schillaci MA, Rompis A, Putra A, Suaryana KG, et al. Primate-to-human retroviral transmission in Asia. Emerg Infect Dis. 2005;11:1028-35. http://dx.doi.org/ 10.3201/eid1107.040957

19. Jones-Engel L, May CC, Engel GA, Steinkraus KA, Schillaci MA, Fuentes A, et al. Diverse contexts of zoonotic transmission of simian foamy viruses in Asia. Emerg Infect Dis. 2008;14:1200-8. http://dx.doi.org/10.3201/eid1408.071430

20. Fuentes A. Human culture and monkey behavior: assessing the contexts of potential pathogen transmission between macaques and humans. Am J Primatol. 2006;68:880-96. http://dx.doi.org/ 10.1002/ajp.20295

21. Haji Saaban S, Sulai P, Rasdi I, Zanudin M, Yatim H, Samsudin AR. Manual for the management of human-macaque conflict in Peninsular Malaysia. Kuala Lumpur (Malaysia): Department of Wildlife and National Parks of Peninsular Malaysia; 2006.

22. PREDICT One Health Consortium 2013. Protocol for primate sampling methods [cited $2015 \mathrm{Apr} 20$ ]. http://www.vetmed.ucdavis edu/ohi/predict/PREDICT_Publications.cfm\#Protocols

23. Seethamchai S, Putaporntip C, Malaivijitnond S, Cui L, Jongwutiwes S. Malaria and Hepatocystis species in wild macaques, southern Thailand. Am J Trop Med Hyg. 2008;78:646-53.

24. Altschul SF, Gish W, Miller W, Myers EW, Lipman DJ. Basic local alignment search tool. J Mol Biol. 1990;215:403-10 http://dx.doi.org/10.1016/S0022-2836(05)80360-2.

25. Wald A, Huang M-L, Carrell D, Selke S, Corey L. Polymerase chain reaction for detection of herpes simplex virus (HSV) DNA on mucosal surfaces: comparison with HSV isolation in cell culture. J Infect Dis. 2003;188:1345-51.

26. Nahass GT, Goldstein BA, Zhu WY, Serfling U, Penneys NS, Leonardi CL. Comparison of Tzanck smear, viral culture, and DNA diagnostic methods in detection of herpes simplex and varicellazoster infection. JAMA. 1992;268:2541-4.

http://dx.doi.org/10.1001/jama.1992.03490180073029

27. Coen DM, Weinheimer S, McKnight S. A genetic approach to promoter recognition during trans induction of viral gene expression. Science. 1986;234:53-9. http://dx.doi.org/10.1126/science.3018926

28. Ohsawa K, Lehenbauer TW, Eberle R. Herpesvirus papio 2: alternative antigen for use in monkey B virus diagnostic assays. Lab Anim Sci. 1999;49:605-16.

29. Smith RD. Veterinary clinical epidemiology: a problem-oriented approach. 2nd ed. Boca Raton (FL): CRC Press LLC; 1995.

30. Hull RN. The significance of simian viruses to the monkey colony and the laboratory investigator. Ann N Y Acad Sci. 1969; 162:472-82. http://dx.doi.org/10.1111/j.1749-6632.1969.tb56398.x

31. Zwartouw HT, Boulter EA. Excretion of B virus in monkeys and evidence of genital infection. Lab Anim. 1984;18:65-70. http://dx.doi.org/10.1258/002367784780864929

32. Van Noordwijk MA, Van Schaik CP. Male migration and rank acquisition in wild long-tailed macaques (Macaca fascicularis). Anim Behav. 1985;33:849-61. http://dx.doi.org/10.1016/S00033472(85)80019-1

33. Weigler BJ, Hird DW, Hilliard JK, Lerche NW, Roberts JA, Scott LM. Epidemiology of Cercopithecine herpesvirus 1 (B virus) infection and shedding in a large breeding cohort of rhesus macaques. J Infect Dis. 1993;167:257-63. http://dx.doi.org/ 10.1093/infdis/167.2.257

34. Whitley RJ, Roizman B. Herpes simplex virus infections. Lancet. 2001;357:1513-8. http://dx.doi.org/10.1016/S0140-6736 (00)04638-9

35. Sawtell NM, Thompson R. Rapid in vivo reactivation of herpes simplex virus in latently infected murine ganglionic neurons after transient hyperthermia. J Virol. 1992;66:2150-6.

36. Boulter EA. The isolation of monkey B virus (Herpesvirus simiae) from the trigeminal ganglia of a healthy seropositive rhesus monkey. J Biol Stand. 1975;3:279-80. http://dx.doi.org/10.1016/ 0092-1157(75)90031-1

37. Weigler BJ, Scinicariello F, Hilliard JK. Risk of venereal B virus (Cercopithecine herpesvirus 1) transmission in rhesus monkeys using molecular epidemiology. J Infect Dis. 1995;171:1139-43. http://dx.doi.org/10.1093/infdis/171.5.1139

38. Huff JL, Eberle R, Capitanio J, Zhou S, Barry PA. Differential detection of $\mathrm{B}$ virus and rhesus cytomegalovirus in rhesus macaques. J Gen Virol. 2003;84:83-92. http://dx.doi.org/10.1099/vir.0.18808-0

Address for correspondence: Jonathan H. Epstein, EcoHealth Alliance, 17th Fl, 460 W 34th St, New York, NY 10001, USA: email:

epstein@ecohealthalliance.org
Table of Contents

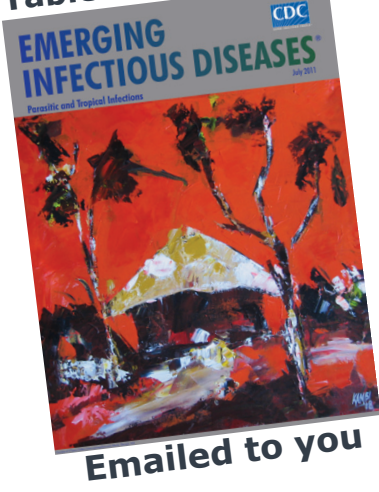

GovDelivery

Manage your email alerts so you only
receive content of interest to you.

Sign up for an Online Subscription:
wwwnc.cdc.gov/eid/subscribe.htm 